\title{
The Complexities of South African Xenophobia on Nigerian Nationals
}

\author{
Yusuf Kamaluddeen Ibrahim*, Abdullahi Ayoade Ahmad and Usman Sufyan Duguri \\ Faculty of Law and International Relations, University Sultan Zainal Abidin, Terengganu, Malaysia.
}

Received: June 25, 2020

Published Online: November 18, 2020

\begin{abstract}
The Nigerian-South African relationship is couched in the paradigm of intricate interdependence. The elements that brought the two African major powers closer include political, cultural, and economic dimensions. Therefore, any dissimilarity of interest between both countries would ruin their relationship and implicate the whole African Union concept that unites Abuja/Pretoria relations. Over 100 South African companies permeate the Nigerian market in several economic sectors and most are successfully operating in Nigeria. Nigerian companies such as First Bank, among others, are also operating in South Africa. As long as South Africa and Nigeria are both dominant powers in their respective sub-regions, a threat like xenophobia needs to be eradicated and coordinate some effective policies for Africa's development. The study employed a qualitative method and library sources, past literature on different xenophobic trends noted in the journal articles, books, and others, on the South African xenophobia and its implications on Nigeria/South African relationship. The study adopted the frustration-aggression theory and it found that incessant xenophobic attacks on Nigerian nationals and other foreigners in South Africa are based on prejudices. The study went further with suggestion to provide some panacea to the catastrophe of South African xenophobia.
\end{abstract}

Keywords: South Africa, Nigeria, Xenophobia, Bilateral Relations, Trade Relations.

\section{Introduction}

The two most powerful countries in Africa that share reciprocity features are Nigeria and South Africa. They were both reliable economy in their respective sub-regional sphere. The former is the leader of the Economic Community of West Africa (ECOWAS), while the latter is the arrowhead of the Southern African Development Community (SADC) (Akinola, 2018). The formulation of the South Africa-Nigeria Bi-National Commission (BNC) in October 1999 is the main focus in this context. The reciprocity of the two countries has had a long history in the African Renaissance and uphold the rebirth of the African continent (Olivier \& Govindjee, 2013). The wave of xenophobia in Africa is a common phenomenon, and it has been practiced in countries such as Ghana, Zimbabwe, Zambia, Botswana, Angola, Nigeria, and South Africa, among others (Akinola, 2018).

In South Africa, prior to the violence, the multinational and bilateral trade relations between both countries have viably progressed; over 100 South African establishments, through the Department of Trade and Industry's support, permeate the Nigerian market in several economic sectors. South African Companies such as the MTN, the Stanbic Merchant Bank Nigeria and 
the Multi-choice Nigeria/M-Net, among others, have been successfully operating in Nigeria. Also, Nigerian establishments such as First Bank, Union Bank, Financial Standard, and Philips Consulting, among others, are also operating in South Africa (Umezurike \& Lucky, 2015). The xenophobic aggression that occurs through despise and ill-treatment of foreigners residing in a particular country erupted to incessant violence and aggression in 2015, towards foreigners living in South Africa, precisely in Johannesburg and Durban; it deteriorated and resulted in army deployment to avert extensive unrest. Also, in 2008 the catastrophes of the phenomenon prevail, led to the murder of more than 60 foreigners and thousands displaced. According to a report by a spokesperson of the National statistics body of South-Africa, there are probably 3.6 million migrants in the country, out of the overall South African population of over 50 million (The Reality Check Team, 2019).

Furthermore, in the South African context, the xenophobia can be dated back to pre-1994. Immigrants faced violence and discrimination in the country, even though such prejudices were ascribed to reputable racism from the Apartheid era (Ogunnubi \& Amusan, 2018). After 1994 transitioning of democracy, the catastrophes of xenophobic incidences escalated and became worrisome in Africa. Hence, Nigeria and South Africa have reciprocity and viable relationship coordinating for the development, peace, and stability of Africa (Dauda et al., 2018). Regrettably, the catastrophe of incessant aggressions and inhumane acts targeted precisely on Nigerian nationals living in South Africa has become quite excruciating. The diplomatic ties between the two have turned sour (Dauda et al., 2018).

Figure-1: Xenophobic Attacks against Foreigners in South Africa

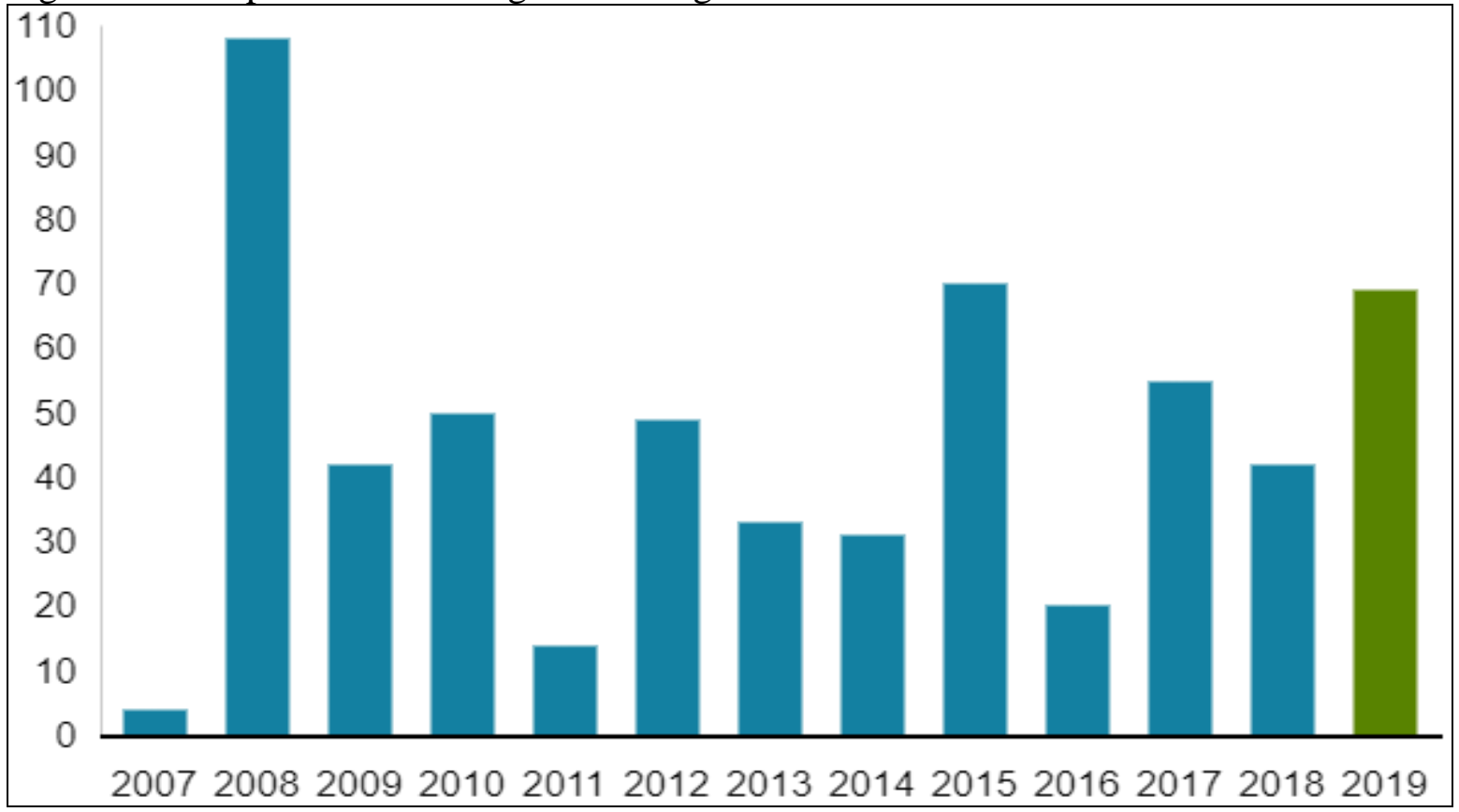

Source: Xenowatch African Center for Migration and Society, 2019

This study focuses on the ill-treatment and victimization meted out on Nigerian nationals in South Africa, and its effects on the Nigerian-South Africans long-term relationship to avert any detachment between the two countries. This study offers great importance to the policymakers, not only on the incidents of South African Xenophobia but also on Africa's overall continent in tackling the menace for the future occurrence and strengthening the diplomatic ties between the two African major powers. It will helps the policymakers in inducing a decisive measure 
in unveiling the prejudice of foreigners, which are bad for a certain country. In addition, it exposes the incessant attacks on Nigerians and other foreigners residing in South Africa. It serves as a tool in publicly shaping the narrative and a prejudice for foreigners for importing human and drug trafficking into South Africa and other related countries (See, Ibrahim \& Ahmad, 2020). It also helps to change the narrative and misinterpretation that foreigners occupy their jobs, businesses, societies, and the economy. It gives a way forward to reiterate and restore ethical basis and virtue, and harmonize the mutual relationship between Abuja/Pretoria and the rest of its allies.

Moreover, the catastrophe of the South African xenophobia is with regard to the citizen's frustration over the insufficient service delivery, which has been the responsibility of the South African government even though the needs of the masses can never be satisfied. Although not directly blameable, the South African government is immensely contributing to the aggressions and incessant attacks on the foreign nationals residing in the country (Mthombeni et al., 2011). According to the report of Human Science Research Council (HSRC), these hostilities and aggressions of South Africans towards foreign nationals is an expression of the citizen's frustration over the insolence and corruption of the government officials, in the security sector, as well as the slow step of consultation, service delivery, and housing administration and provisions (Webb, 2008).

The aggression has deteriorated in South Africa, which resulted in some of Zambia's football team and Nigerian singers publicly boycotted the country due to multiple days of violence, looting, and butchering non-South Africans living in the country. The Nigerian government boycotted the World Economic Forum (WEF) meeting held in Cape Town. The Nigerian government issued a warning to its citizens traveling to South Africa and advised the citizens to refrain from traveling to volatile and high-risk areas until the condition is stable. The South African President Cyril Ramaphosa has publicly condemned the aggressions and attacks and urged "South Africa is home to all." His plea does not quench the agony and consequence across Africa; trends emerged of retaliatory attacks on South Africans and their businesses living across Africa (Nkosi, 2019).

\subsection{The Theoretical Approach}

This study is guided by the Frustration-aggression theory pioneered by (Dollard et al., 1939). The theory implies that "aggression is often a consequence of frustration and contrariwise. The incessant frustration often storms into some sort of aggression," when there is annihilation or impediment from goal attainment (Dollard et al., 1939). When individuals or group of people tried to reach or achieve their goals, and some sort of annihilation appeared to stand between their desire of goal attainments, used to resulted in aggressions that if care was not taking becomes disastrous and catastrophes to innocent society, and also, if the government palliatives and measures set in place to curb the frustration failed to untangle the knot that erupted into aggression, it usually led to a catastrophe of attacks and unbearable pain on innocent targets, such as male, woman, young and the aged (Pastore, 1950).

The incessant xenophobic attacks on Nigerian nationals by South Africans are a result of the citizen's frustration towards their government, which led to aggression and violence. The incessant attacks on Nigerians by the South Africans can regrettably succeed in dismantling the long-term cordial relationship between the two African major powers. The citizens of South Africa weigh their decades of frustration on foreigners residing in their country. The foreigners 
are perceived as the ones impeding or blocking the locals from achieving their goals in areas of employment, businesses, and other social activities. Lack of a conducive and productive environment is the root-cause of aggression in the country, serving as a threat to both countries' relationships. For example, the foreign policy of Nigeria ensures both the protection as well as the safety of rights and property within and outside the country. Any breach or violation of its citizens' rights or property by any country without equitable cause can impact Nigerian relations with such a country. As other nationals from foreign nations conduct their businesses or other activities in Nigeria, Nigerians are also residing in other countries for businesses and other purposes. It is a core responsibility on the part of the host country to make sure that all measures are taken for the safety and protection of the lives and properties of both the natives and the foreigners living legitimately in their country.

Furthermore, Several studies such as Harris (2001), Haigh \& Solomon (2008), Matzopoulos et al., (2009) among others claimed that the apartheid era is the influence that installed a xenophobic mindset in South Africa through the oppression of the black citizens during the era, it developed mistrust, close-minded, and suspicions towards foreigners living in the country. According to Nyamnjoh (2006) and Harvey et al., (2008), the contemporary transition into globalization had brought about an influx of migrants and refugees into a certain country. Such circumstance had alerted both the South African locals and the foreigners on the sense of belonging and the trait of citizenship, which intensified their anxieties and uncertainty into vicious xenophobic practices because of the emergence of the country as regional leader with prosperous economy amidst top industrialized countries in Africa.

Also, Whiteman \& Hendricks (2004), Burns (2008: 120), Nyamnjoh (2006: 5) has elaborated that the liberal nature of the foreign policy of South Africa can be recognized among the factors igniting xenophobia in the country. Nyamnjoh added that the government of South Africa endorsed the method of political and economic liberalism, whereby the predilection of equity without justice was implemented. The present study is to bridge the gap left by the past studies on how the South African incessant xenophobic attacks on the Nigerian national's which affected the Abuja/Pretoria bilateral relations which was not elaborated sufficiently by the previous studies, to strengthen the diplomatic ties between the African major powers and the entire African continent.

\subsection{History of the Xenophobia in Africa}

The experience of colonialism in Africa militarised societies and installed vicious character upon the African states, which resulted in the institutionalized culture of violence among the communities and the state. These illustrate the vast series of civil war, political instability, terrorism, and insurgency experienced by many countries in Africa (Akinola, 2018). The menace has recently become attached to the African story, though it is not a new phenomenon; its destructive nature is a point of concern between African stakeholders in security, development, and peace projects. From Zambia to South Africa and Ghana to Nigeria, aggressions have been waging against each-other among non-citizens of the same African descent (Akinola, 2018). Relatively, in 1969, under the Kofi Busia regime, " the government of Ghana deported over 20,000 Nigerians under the pretence of Aliens Compliance Order" (Gocking, 2005).

Similarly, "in 1983 and 1985, Nigeria, in retaliation, deported Ghanaian nationals residing in the country via Alien and Immigration Law; and the same occurred in Uganda, Angola, Kenya, 
and Cote d'Ivoire, Chad, South Africa, and Gabon, among others" (Neocosmos, 2010). The xenophobic reaction in counties such as Nigeria, Angola, South Africa, Uganda, and Ghana was ascribed to their economic condition. The action of xenophobia in Chad and Kenya were attributed to the war on terror. In addition, the prejudices of xenophobia in Gabon, Equatorial Guinea, and Cote d'Ivoire were resonated with the economic and political situation. The Angolans deportation by Congo Kinshasa was due to the country's political condition (Aremu \& Ajayi, 2014).

Furthermore, "the notion behind the expulsion of foreign nationals among African countries is to build opportunities for the aborigines to prosper in their own land" (Oni \& Okunade, 2018). This has developed disputes in the countries of Africa where xenophobia occurs; lost it in mind that foreigners residing in each country of Africa are either with direct or indirect actions injecting to the economic growth of the host country (Hickel, 2014). Nonetheless, any country whose nationals were expelled or rejected due to xenophobia may definitely affect their goodterm relations with the host country. Hence, Africans' hatred by Africans and other xenophobic acts were totally condemned in Africa's continent (Brobbey, 2018). Notably, the speed at which the phenomenon occurs in South Africa induced severe distress among the African states. It is noted that the xenophobia in Nigeria, Ghana, and related countries did not involve violence (Chandia \& Hart, 2016). It imply that none of the African xenophobia displayed intensity, in the manner that the xenophobic attacks of South Africa launched on other nationals residing in the country brutally unveiled (Oni \& Okunade, 2018).

\subsection{Genesis of Xenophobia in South Africa}

In the South African context, xenophobia can be dated back to pre-1994, in which immigrants faced violence and discrimination in the country, even though such actions were ascribed to the established racism from the Apartheid rule (Ogunnubi \& Amusan, 2018). The government has been confounded with a rapid influx of legitimate and illicit foreign migrants permeating the country. It is reported that more than 2.2 million foreigners from 53 African States were residing in South Africa (Molatlhwa, 2012). The South African statistical record revealed that among the entire African countries, Zimbabwe and Mozambique have the highest immigrants, followed by those living in South Africa (Molatlhwa, 2012). Relatively, the conducive atmosphere and industrialized setup of South Africa made it among the top countries in Africa, where foreigners that visit for tourism were intriguing to stay (Dyson et al.,2015).

The South African industrialized setup made it unique among other African states due to its flexible economic nature that attracts people from all corners of life to migrate there (Adeogun $\&$ Faluyi, 2018). The country started employing foreign nationals since the discovery of gold in the nineteenth century (Adeogun \& Faluyi, 2018). As a result, the country was able to experience the inflow of foreign nationals or immigrants from Africa and various parts of the world (Adam \& Moodley, 2013). The process of employing black immigrants as miners working for the mining industry has been around even amidst the apartheid-era in South Africa; from that moment, henceforth, the South African aborigines often despised foreign immigrants and regard them unwanted in their country (Fayomi et al., 2015).

Furthermore, the country's comfortable environment and the industrialized nature attract the migrants' inflow, such as those seeking a refuge from the war, poverty, unfavourable policies of the government, and the economic crises in their different nation-states (Solomon \& Kosaka, 2013). According to the UNHCR (2019) report, South Africa hosted over 310,000 in 2014 and 
260,000 in 2019 which included asylum seekers, refugees, and immigrants via open door policy and hospitality of the country. The foreigners were hosted from Ethiopia, Zimbabwe, and Nigeria, among other African nations. This caused an incretion in the South African daily population and persuaded South Africans to assume that the black immigrants have illegally come into the country.

Gumede (2015) noted on this perspective that this is the main factor igniting Xenophobic, Negrophobic, and Afrophobic violence in the country. It had also coupled with the incidence of discrimination from the Apartheid experience that instilled racist prejudices in South Africa (Kalitanyi \& Visser, 2010). As such, the aggression has erupted into chaos and violence whereby South Africans allegedly threw foreigners out from a moving train due to the conspiracy that foreigners were the ones occupying their jobs and transporting diseases into their country (Misago et al., 2015).

The transition of 1994 from apartheid rule into democracy changed and reduced the aggressions, prejudices, and rising xenophobic violence. Nyamnjoh (2006) described the xenophobia of South Africa as an influence of globalization. He further claimed that "globalization intensified insecurities induced by the borderless flow of goods, information, and capital on a large scale, which has developed an obsession of belonging and citizenship." The citizen's aggressions, which turned into incessant attacks raged on the foreign nationals residing in South Africa, erupted in May 2008 in the Alexandra township in Johannesburg (Tafira, 2018). It resulted in the loss of about 64 lives of non-South Africans and displaced thousands who survived severe injuries, raped, and dilapidated properties worth millions of Rand's (Tafira, 2018). The vicious act was related to the 1835 and 1846 wars in which the campaign called "Buyelekhaya," implying that "go back home" waged on foreigners living in the country (Akinola, 2018).

\section{Research Methodology}

The study employed a qualitative descriptive document with a library source method and used past literature on different types of xenophobia, especially the xenophobia in Africa, with a particular emphasis on the South-African xenophobic violence which has meted on the Nigerian nationals. The past studies used for this research include the journal articles, books, newspapers, and research reports, among others, to allow the researcher to figure out the strength and weaknesses of the past studies and to pave a way in addressing the gap and untangle the knot of the menace.

The phenomenon of xenophobia drew the attention of a number of researchers, which led to the publication of a number of scholarly works on the subject matter. The present research, despite its limitations in elaborating only the South African xenophobia in Africa, has filled some gaps in illustrating the scenario of the South African aggressions and an incessant xenophobic attack on foreigners, precisely the Nigerian nationals residing in the country. It also highlights its implications on the Abuja/Pretoria bilateral relations that previous studies did not fill, in order to fill the vacuum left by the earlier studies and suggested a panacea for the menace of xenophobia in Africa as well as the whole world.

Furthermore, the current research is an exploratory study that adopted a qualitative approach in scrutinizing the impacts of the South African catastrophe of xenophobia on precisely the Nigerian citizens as well as other Africans. Therefore, this study's findings could be used as 
variables to conduct qualitative and quantitative research to disclose the significance and impact of one variable over other using in-depth and rigorous thematic qualitative or other quantitative statistical tools.

\section{Historical Context of Nigeria and South African Bilateral Relations}

Nigeria stood firmly in opposing apartheid rule throughout the 1960s and 1970s, partaking in Frontline States (FLS) meetings of African states, advocating at the commonwealth against the apartheid era, and leading the UN special anti-apartheid committee. However, in 1994 after the transition to democracy, the Nobel prize winner and South African new president Nelson Mandela emerged as the transformative South African leader, in which Nigeria was historically dominating (Akinola, 2018). The two countries' relations become sour when autocratic Nigerian leader General Sani Abacha ignored Mandela's appeal and executed Nigerian activist Ken Saro-Wiwa with eight other Ogoni in November 1995 (Zwane et al., 2014). Nigeria's oil export was boycotted, followed by a Commonwealth suspension with the support of South Africa (Landsberg et al., 2007). However, most African countries failed to support Mandela's stance on the issue broadly. After the demise of the Nigerian autocrat General Sani Abacha, the new civilian president of Nigeria, Olusegun Obasanjo, and Mandela's successor president Thabo Mbeki in 1999 embarked on viable efforts in breaching the diplomatic gap between the two countries to tackle African conflicts and encourage new norms of democratic governance via continental institutions (Adebajo, 2012).

Furthermore, in Nigeria and South Africa in 1999 established the Bi-National Commission. Subsequently, under the regime of President Jacob Zuma, South Africa changed its focus from Nigeria to Angola to strengthen its Southern African alliances and a strategic partner in Africa. In May 2008, the Nigerian press condemned Tshwane (Pretoria) over its negligence to end xenophobic attacks in South Africa precisely on Nigerian nationals (Akinola, 2018). The two former vice president's tenure (Jacob Zuma and Good luck Jonathan) who later become president in their respective countries engaged in unfavorable diplomatic rivalry, while the focus of South Africa turned to Angola and other African nations due to its membership in BRICS and G20 (Fakunmoju et al., 2015). Relatively, Nigeria adopted a contrary stance against South Africa on African Union (AU) and UN Security Council over the French/UN military intervention in Cote d'Ivoire and National Transitional Council (NTC) on Libya's new government transition. Also, a South African customs official in March 2012 denied 125 Nigerian travelers; Nigeria retaliated by turning away 78 South African travelers from entering into the country (Carciotto \& D'Orsi, 2017).

\subsection{The Diplomacy of Nigeria-South Africa Bilateral Relations}

Even though the diplomatic relations of two countries have started in 1994, their high commissions in Tshwane and Abuja were formed in 1995 and 1996, respectively. Their relationship became sour when Nelson Mandela pursued international sanctions on the regime of General Sani Abacha. However, the golden age of bilateral relations was initiated after 1999 by president Obasanjo and Mbeki, promoting new African institutions and developing efforts to strengthen the diplomatic ties between the two (Benyera, 2018). Both country's high commissioners had relatively been allowed access to their host presidents. They coordinated their coherent efforts towards key UN and AU meetings (Obi, 2015). A Bi-National Commission was established with seven meetings held between 1999 and 2008, and 20 key bilateral agreements were signed in 2003. Even though, in 2005, tensions over permanent 
African representatives to the UN Security Council, AU Assembly of heads of government and state, and the Mbeki's mediating role in Cote d'Ivoire had emerged between the nations. Relatively, after 2008, none BNC full session had been held for four years. The eighth BNC full session occurred in May 2012 in Cape town, attributed to reciprocity restoration and bilateral relations (Akinola, 2018).

\subsection{Nigeria-South African Multilateral Relations}

Both Nigeria and South Africa have coordinated the primacy of the AU in authorizing nonpermanent African representatives to the Council, in which in 2005, South Africa consistently insisted on "Ezulwini Consensus," which is demanding for two permanent seats for Africa and five rotational ones as a substitute to the three existing non-permanent seats assigned to the continent. Both countries implemented mutual responses to security challenges in Africa, such as the top-key police and troops contributing countries to the UN peacekeeping missions in the continent (Akinola, 2018). The two work collectively in multilateral entities such as the World Bank, Commonwealth, the Non-Aligned Movement (NAM), and the International Monetary Fund (IMF). However, Nigeria opposed South Africa's home affairs minister Nkosazana Dlamini-Zuma as a chair nominee of the AU Commission, which, fortunately, Dlamini-Zuma won with 37 votes in the fourth round, after a fiercely and protracted disputed election in July 2012. Although the country claims that its actions did not violate any legal AU rules, Nigeria, as well as other several countries, questioned whether it was politically wise (Akinola, 2018).

\subsection{The Future of Nigeria-South African Relations}

The two countries need to consistently work on their differences to manage and communicate under the realm of a formal reciprocity institution such as the Bi-National Commission. The BNC, which was formed in May 2012 in Cape Town, for the prospect of Nigeria-South Africa to "reset" their relationship. Also, viable agreements on technical and economic spheres were signed at the meetings, such as migration issues, economic cooperation, customs procedures, terrorism, cybercrime, extradition and mutual legal aid, and investment protection. Relatively, new contracts were also proposed in areas such as science and technology, minerals and energy, aviation, agriculture, and defence. They further agreed that BNC focal points should be established at the high commissions of the two countries (Abuja/Tshwane). Also, implementation committee meetings will be conducted every six months to go-through BNC's decision progresses. Prospective meetings have been organized for working groups on trade, foreign Affairs, security and defence, industry and finance, mineral and energy, infrastructure and public enterprise, technical and social affairs, as well as constitutional and communications issues. Lastly, the BNC suggested that immigration and the consular forum will hold meetings monthly to revive the bilateral Presidential Council on Investment.

\section{Conclusion}

South Africa and Nigerian diplomatic and economic ties that have been established via reciprocity relationship between both nations in the continent of Africa may have become sour due to attacks targeted on Nigerians in South Africa; if such occurred will jeopardize the role that both countries play cooperatively in ensuring development in Africa (Koutonin, 2016). Historically, the foreign policy of Nigeria and South Africa towards Africa showed commitment to favour the entire continent of African stability, socio-economic wellbeing, and leadership role (Uneze et al., 2017). Nigeria's long history of Afrocentric policy commitment, 
especially it's support on the campaign against the apartheid in the continent, which has led to the formulation of the UN special committee against the apartheid as a result of the Nigerian government's valance and other countries in Africa (Yusuf et al.,2019). Prior to the incidence in South Africa, the multinational and bilateral trade relations between both countries have workably progressed; over 100 South African companies, through the Department of Trade and Industry`s support, permeate the Nigerian market in several economic sectors.

South African companies such as; MTN, Stanbic Merchant Bank Nigeria Ltd, and Multi-choice Nigeria/M-Net, among others, are successfully operating in Nigeria; also, Nigerian establishments such as First Bank, Union Bank, Financial Standard and Philips Consulting among others, are also operating in South Africa (Umezurike \& Lucky, 2015). Nigerian nationals' incessant attacks by South Africans have been perceived by Nigeria that "South Africa is reflecting as ungrateful" (Ogunnubi \& Amusan, 2018). The vicious attacks by South Africans on foreigners were based on the aggression and prejudices that immigrants are the ones controlling their economy, taking their jobs, and spreading deadly illnesses among their society (Unah, 2017). The menace has provoked Nigeria's government, condemning the barbaric and illicit act in Africa and Nigerian Diaspora. The Nigerian Foreign Affairs urged for AU immediate intervention so as to bring an end to the vicious act in South Africa. The government of South Africa needs to strictly induce decisive measures to safeguard both the Nigerians and the other Africans residing within their land.

\subsection{Recommendations}

This paper suggests that leaders of South Africa have the viability to confront such challenges and disregard or condemn actions of the politicians who are advocating for negative media reporting to portray foreigners as bad for the country. They are blaming foreigner for importing prostitution, drug, and human trafficking into the country, in order to destroy the prejudice of foreigners are the ones occupying their jobs, their businesses, societies, and their economy and to restore the political and economic reciprocity of the two countries. Solomon (2003) claims that it is simple for the government and the media to paint foreigners for employment, housing issues, and crimes. It is still an unreliable resort and can tarnish South Africa's reputation, society, culture, economy, and image abroad. Evidently, the South African foreign policy was designated to better South Africa, the African continent, and a better world. The South African leaders promoted the African Renaissance, which the country uses auspiciously to expand business trudges in the African continent (Umezurike \& Lucky, 2015). Following are the recommendations based on the Bi-National agreement signed by Nigeria/South Africa in 2012 in order to strengthen the two countries bilateral relationship:

a) To enhance the strategic partnership between the two countries, a reliable mechanism needs to be institutionalized, including promoting effective monitoring and implementing the active Bi-National Commission mechanism. In addition, the establishment of the focal point at both countries mission (Tshwane and Abuja) should ensure proper consultation at points of director-general and permanent secretary as well as communicating their decision at the local government and provincial level, which could assist the BNC's efforts, and should also be granted access to both host countries leaders in order to strengthen the bilateral ties and effective implementation;

b) Both countries should establish "deploying former and current foreign policy experts and senior officials," to prevent eruptive diplomatic incidents and act as fast-channels in the 
situation of violence and crisis such as xenophobia and regulate both sides to "resort" their diplomatic tension;

c) The two countries BNC focal points should embark on tremendous public visibility for bilateral events and visits to draw the civil society's total dedication to their work, mainly to counter common prejudices and advocate the media to educate the masses more effectively about the merits of the two countries' close cooperation on the nature and extent of historical and current political, business fora, trade unions, sports clubs, militaries, cultural groups and socio-economic relations to strengthen and motivate both citizens about the benefits of establishing friendship between the two countries;

d) The proposed agreement on free trade between South Africa and Nigerian through BNC in 2012 should be revived to change none and high tariff barriers that constrain intra-African trade. There is a need to develop a political commitment to allow free trade between SADC and ECOWAS in the long term, and also to provide a trade corridor in a medium-term between the two sub-regions, so as to encourage Africa's regional integration and socioeconomic development;

e) The two countries should work-together more closely in representing Africa's interest in the international fora and multinational bodies, including the G20 in which the sole African country is South Africa. Through the BNC foreign affairs committee process, as proposed in 2012 by BNC, South African and Nigerian diplomats in New York, Vienna, Geneva, and Addis Ababa should prioritize both countries' prospected positions in the international bodies to uplift the interest of Africa more effectively. And finally;

f) The two countries should resettle their dissimilarities over nominations and senior officials' representations to the AU Commission and other international organizations. The focus should be channelled into mechanism to develop an agreement on formalizing the process of how AU should select the UN Security Council and a non-permanent representative. For instance, African major powers should be rotating one of the three non-permanent seats; African middle power rotates the second seat, and the continent's smaller states rotate the third seat, respectively, so that mutual understanding of peace and harmony is restored among the entire African continent.

\section{References}

Adam, H., \& Moodley, K. (2013). Imagined liberation: xenophobia, citizenship, and identity in South Africa, Germany, and Canada (Vol. 4): African Sun MeDIA.

Adebajo, A. (2012). Paradise lost and found: the African Union and the European Union. The EU and Africa: From Eurafrique to Afro-Europa. Hurst \& Company. https://www.chathamhouse.org/sites/default/files/public/Research/Africa/030912su mmary.pdf

Adebajo, A., Adedeji, A., \& Landsberg, C. (2007). South Africa in Africa: the post-apartheid era. University of Kwazulu Natal.

Adeogun, T., \& Faluyi, O. (2018). Xenophobia, Racism, and the Travails of 'Black' Immigrants in South Africa. The political economy of xenophobia in Africa (pp. 125134). Switzerland: Springer, Cham. https://doi.org/10.1007/978-3-319-64897-2_10

Adjasi, C., Harvey, S. K., \& Agyapong, D. A. (2008). Effect of exchange rate volatility on the 
Ghana stock exchange. African Journal of Accounting, Economics, Finance, and Banking Research, 3(3), 1-20. https://ssrn.com/abstract=1534178

Akinola, A. O. (2018). The Political Economy of Xenophobia in Africa. https://link.springer.com/book/10.1007\%2F978-3-319-64897-2\#about

Benyera, E. (2018). Is the international criminal court unfairly targeting Africa? Lessons for Latin America and the Caribbean States. Politeia, 37(1), 1-30. https://dx.doi.org/10.25159/0256-8845/2403

Brobbey, C. A. B. (2018). Democratization and legitimization of xenophobia in Ghana. In The political economy of Xenophobia in Africa (pp. 69-79). Springer. https://doi.org/10.1007/978-3-319-64897-2_6

Burns, J. K. (2008). Xenophobia-evolved 'outgroup' hatred or product of a toxic social environment? South African Journal of Psychiatry, 14(4), 120-121. https://www.ajol.info/index.php/sajpsyc/index

Carciotto, S., \& D’Orsi, C. (2017). Access to Socio-Economic Rights for Refugees: A Comparison Across Six African Countries. Cape Town. https://ilpanetwork.org/wpcontent/uploads/2017/03/2367_SIHMA_Research-Report_WEB3.pdf

Chandia, M., \& Hart, T. G. B. (2016). An alien in the country of my birth: Xenophobia reinforcing otherness and promoting exclusion. Agenda, 30(2), 28-34. https://doi.org/10.1080/10130950.2016.1196987

Choane, M., Shulika, L. S., \& Mthombeni, M. (2011). An Analysis of the Causes, Effects, and Ramifications of Xenophobia in South Africa. Insight on Africa, 3(2), 129-142. https://doi.org/10.1177/0975087814411138

Dauda, M., Sakariyau, R. T., \& Ameen, A. (2018). Xenophobic violence in South Africa and the nigerians' victimization: An empirical analysis. Pertanika Journal of Social Sciences Humanities, 26(4), 2677-2700. http://www.pertanika.upm.edu.my/Pertanika\%20PAPERS/JSSH\%20Vol.\%2026\%2 0(4)\%20Dec.\%202018/32.\%20JSSH-2197-2017.pdf

Dollard, J., Miller, N. E., Doob, L. W., Mowrer, O. H., \& Sears, R. R. (1939). Frustration and aggression. Yale University. https://psycnet.apa.org/doi/10.1037/10022-000

Dyson, L. L., Van-Heerden, J., \& Sumner, P. D. (2015). A baseline climatology of soundingderived parameters associated with heavy rainfall over Gauteng, South Africa. International Journal of Climatology, 35(1), 114-127. https://doi.org/10.1002/joc.3967

Fakunmoju, S. B., Bammeke, F. O., Oyekanmi, F. A. D., Rasool, S., George, B., \& Lachiusa, T. A. (2015). Attribution of blame to victim and attitudes toward partner violence: Cross-national comparisons across the United States, South Africa, and Nigeria. http://196.45.48.59/bitstream/handle/123456789/4960/Attribution_of_Blame_to_Vi ctim_and_Attitudes_towar.pdf?sequence $=1 \&$ isAllowed $=y$

Fayomi, O. O., Chidozie, F. C., \& Ajayi, L. A. (2015). Nigeria's National Image and Her Foreign Policy: An Exploratory Approach. Open Journal of Political Science, 5(3), 180-196. https://doi.org/10.4236/ojps.2015.53019

Gocking, R. (2005). The history of Ghana. Greenwood Publishing.

Gumede, V. (2015). Exploring thought leadership, thought liberation, and critical consciousness for Africa's development. Africa Development, 40(4), 91-111. https://www.ajol.info/index.php/ad/article/view/150608

Haigh, L., \& Solomon, H. (2008). Responding to xenophobia in South Africa. Briefing Paper (Vol. 27). Pretoria. https://doi.org/10.3138/jcfs.46.1.39

Harris, B. (2001). A foreign experience: violence, crime and xenophobia during South Africa's 
transition. Violence and transition series. http://xenophobia.org.za/experience.pdf

Hickel, J. (2014). "Xenophobia" in South Africa: order, chaos, and the moral economy of witcheraft.

Cultural

Anthropology,

$29(1)$

103-127. https://doi.org/10.14506/ca29.1.07

Ibrahim, Y. K. \& Ahmad, A. A. (2020). The causes of kidnapping and its implications on Nigeria. Liberal Arts and Social Sciences International Journal (LASSIJ), 4(1), 1-9.

Kalitanyi, V., \& Visser, K. (2010). African immigrants in South Africa: job takers or job creators? South African Journal of Economic \& Management Sciences, 13(4), 376$390 . \quad$ http://www.scielo.org.za/scielo.php?script=sci_arttext\&pid=S222234362010000400001

Koutonin, M. R. (2016). Nigeria's role in ending Apartheid in South Africa. Silicon Africa News Paper Online. https://journal.unisza.edu.my/apj/index.php/apj/article/view/107

Matzopoulos, R., Corrigall, J., \& Bowman, B. (2009). A health impact assessment of international migrants following the xenophobic attacks in Gauteng and the Western Cape. University of the Witwatersrand.

Misago, J. P., Freemantle, I., \& Landau, L. B. (2015). Protection from xenophobia: An evaluation of UNHCR's regional office for Southern Africa's xenophobia related programmes. In University of Witwatersrand, ACMS.

Molatlhwa, O. (2012). Women in Mini Skirts Attacked at Taxi Rank. Sowetan Live. http://scholar.sun.ac.za/handle/10019.1/97926

Neocosmos, M. (2010). From foreign natives to native foreigners. Explaining xenophobia in post-apartheid South Africa: Citizenship and nationalism, identity and politics. African Books Collective.

Nyamnjoh, F. B. (2006). Insiders and outsiders: Citizenship and xenophobia in contemporary Southern Africa. Zed Books.

Obi, C. (2015). Repositioning South Africa in global economic governance: A perspective from Nigeria. South African Journal of International Affairs, 22(2), 165-184. https://doi.org/10.1080/10220461.2015.1054305

Ogunnubi, O., \& Amusan, L. (2018). Nigeria's attitude towards South Africa's perceived xenophobia: Exploring a shared hegemonic power for Africa's development. The political economy of xenophobia in Africa (pp. 53-67). Switzerland: Springer. http://ndl.ethernet.edu.et/bitstream/123456789/62150/1/355.pdf.pdf\#page=59

Olaosebikan, A. Ohnson, \& Ajayi, A. T. (2014). Expulsion of Nigerian immigrant community from Ghana in 1969: causes and impact. Developing Country Studies, 4(10), 176-186. http://citeseerx.ist.psu.edu/viewdoc/download?doi=10.1.1.1001.933\&rep=rep1\&typ $\mathrm{e}=\mathrm{pdf}$

Olivier, M., \& Govindjee, A. (2013). Labour rights and social protection of migrant workers: In search of a coordinated legal response. Inaugural Conference of the Labour Law Research Network (LLRN), Barcelona, Spain, 13-15. https://open.uct.ac.za/bitstream/handle/11427/22905/thesis_law_2016_biney_elizab eth.pdf?sequence $=4 \&$ is Allowed $=\mathrm{y}$

Oni, E. O., \& Okunade, S. K. (2018). The Context of Xenophobia in Africa: Nigeria and South Africa in Comparison. https://doi.org/10.1007/978-3-319-64897-2_4

Onyekwena, C., Ademuyiwa, I., \& Uneze, E. (2017). Trade and foreign direct investment nexus in West Africa: does export category matter? Investment and Competitiveness in Africa (pp. 109-133). Springer. https://doi.org/10.1007/978-3-319-44787-2_6

Pastore, N. (1950). A Neglected Factor in the Frustration-Aggression Hypothesis: A Comment. Journal of Psychology: Interdisciplinary and Applied, 29(2), 271-279. 
https://doi.org/10.1080/00223980.1950.9916032

Philip, K., Tsedu, M., \& Zwane, M. (2014). The impact of social and economic inequality on economic development in South Africa. UNDP.

Solomon, H., \& Kosaka, H. (2013). Xenophobia in South Africa: Reflections, narratives, and recommendations. Southern African Peace and Security Studies, 2(2), 5-30. http://www.saccps.org/pdf/2-2/SAPSS\%202(2)\%20Solomon\%20\&\%20Kosaka.pdf

Tafira, H. K. (2018). Inside the Mind of a Xenophobe. Xenophobia in South Africa (pp. 3553). Springer. https://doi.org/10.1007/978-3-319-67714-9_3

Umezurike, S. A., \& Lucky, A. E. (2015). Exploring Diplomatic Crisis of Nigeria and South Africa between 1994 and 2013. Academic Journal of Interdisciplinary Studies, 4(1), 65-73. https://doi.org/10.5901/mjss.2015.v4n1p65

Unah, L. (2017). Who is South Africa to humiliate Nigeria? African Arguments, 2(1), 24.

Webb, B. (2008). Xenophobia used by right-wing populists. Star, 3(1), 10. https://doi.org/10.31920/2634-3649/2020/10n2a2

Whiteman, K., \& Hendricks, C. (2004). South Africa in Africa: The Post Apartheid Decade. Centre For Conflict Resolution (CCR). https://www.africaportal.org/publications/south-africa-africa-post-apartheid-decade/

Yusuf, F. O., Ifijeh, G., \& Owolabi, S. (2019). Institutional Repositories in Africa: Issue and Challenges. Landmark University, Nigeria. https://doi.org/10.4018/978-1-5225$\underline{8437-7 . \operatorname{ch} 008}$

Reality check team (October 2, 2019). South Africa: How common are Xenophobic attacks, Reality check, BBC News. https://www.bbc.com/news/world-africa-47800718

Wachiaya, C. (2019). UN refugee chief visits South Africa to show support for government and refugees. https://www.unhcr.org/en-my/news/latest/2019/10/5da6d73624/unrefugee-chief-visits-south-africa-show-support-government-refugees.html

Nkosi, M. (2019). Stars boycott South Africa over xenophobia attacks. BBC News. https://www.bbc.com/news/world-africa-49576397

Last updated: January 24, 2022 